\title{
GAMBARAN PENGGUNAAN SEMEN IONOMER KACA SEBAGAI \\ BAHAN TUMPATAN GIGI DI BALAI PENGOBATAN RUMAH \\ SAKIT GIGI DAN MULUT UNIVERSITAS \\ SAM RATULANGI PADA TAHUN \\ 2011 SAMPAI 2012
}

\author{
${ }^{1}$ Gizela Stephanie Saerang \\ ${ }^{2}$ B.S Lampus \\ ${ }^{3}$ Dinar A. Wicaksono
}

\footnotetext{
${ }^{1}$ Kandidat skripsi Program Studi Kedokteran Gigi Fakultas Kedokteran Universitas Sam Ratulangi

${ }^{2}$ Bagian Ilmu Kesehatan Masyarakat Program Studi Kedokteran Gigi Fakultas Kedokteran

Gigi Universitas Sam Ratulangi

${ }^{3}$ Bagian Ilmu Konservasi Gigi Program Studi Kedokteran Gigi Fakultas kedokteran

Universitas Sam ratulangi

Email: gizelasaerang@ymail.com
}

\begin{abstract}
Caries is a disease most commonly found in the oral cavity so that is the main problem of oral health. Dental caries should be taken care of by filling. Nowadays have been found filling materials for caries in example glass ionomer cement (GIC). At the Dental Clinic of Sam Ratulangi University, GIC is the preferred material often chosen by dentists for caries.

The purpose of this research is ti know abaout the use of GIC as restoration material in the Dental Clinic of Sam Ratulangi University in 2011-2012. This research is a descriptive retrospective research using the cross sectional approach by taking the medical records of patients in the Dental Clinic of Sam Ratulangi University whom were given GIC as the filling material. The amount of research data retrieved were of 247 patients with 355 teeth filled by GIC and categorized based on the year of fillng, age,sex, region of feeling and the period of teeth in each patient.

The results show that in the year of 2012 the use of GIC restorations has increased in comparison to the year 2011. Treatment with a GIC is more often accepted by female patients and most of them were children. The posterior region of the teeth is the region most filled by GIC and most of the period of permanent teeth.
\end{abstract}

Keywords: glass ionomer cement, filling 
Abstrak: Karies merupakan salah satu penyakit yang paling banyak dijumpai di rongga mulut sehingga merupakan masalah utama kesehatan gigi dan mulut. Perawatan untuk gigi yang mengalami karies salah satunya bisa dengan cara ditumpat. Saat ini telah banyak ditemukan bahan tumpatan untuk karies gigi, contohnya semen ionomer kaca (SIK). Di Balai Pengobatan Rumah Sakit Gigi dan Mulut (BP-RSGM) Universitas Sam Ratulangi, SIK merupakan salah satu bahan tumpatan yang sering dipilih oleh dokter gigi pada pasien yang mengalami karies.

Penelitian ini bertujuan untuk mengetahui gambaran penggunaan SIK sebagai bahan tumpatan gigi di BP-RSGM Universitas Sam Ratulangi pada tahun 2011-2012. Jenis penelitian ini merupakan penelitian deskriptif yang menggunakan metode studi cross sectional dengan pengambilan data dari rekam medis pasien yang ditumpat dengan SIK di BP-RSGM Universitas Sam Ratulangi. Jumlah data penelitian yang dambil yaitu 247 pasien dengan 355 gigi yang ditumpat dan dikategorikan berdasarkan tahun penumpatan, usia, jenis kelamin, regio dan periode gigi yang di tumpat pada setiap pasien.

Hasil penelitian menunjukkan pada tahun 2012 telah terjadi peningkatan dalam penggunaan SIK dibandingkan pada tahun 2011. Perawatan SIK lebih sering dipakai oleh pasien perempuan dan sebagian besar berusia anak-anak. Regio posterior merupakan regio gigi yang paling banyak mendapatkan tumpatan SIK dan paling banyak pada periode gigi permanen.

Kata kunci: semen ionomer kaca, penumpatan

Mempertahankan tubuh tetap sehat adalah sasaran yang harus dicapai setiap praktisi medis, demikian halnya juga dengan dokter gigi. Dokter gigi juga harus mencegah atau menahan proses penyakit serta mengembalikan bagian gigi yang hilang. Seringkali kedua sasaran tersebut dicapai dengan pembuatan suatu tumpatan sederhana (restorasi).

Kebanyakan pasien yang datang untuk mendapat perawatan gigi juga mementingkan nilai estetik dari gigigeliginya. Hal tersebut penting sebagai pertimbangan dalam pemilihan bahan tumpatan yang digunakan. Bahan restorasi harus semirip mungkin dengan gigi asli yang digantikan. Hal ini dikarenakan gigi ini akan terlihat selama pergerakan fungsional yang normal.

Saat ini telah banyak ditemukan bahan tumpatan untuk karies gigi. Salah satu syarat suatu bahan restorasi yang ideal selain dari sisi estetik juga harus bisa beradaptasi baik dengan kavitas, tidak menimbulkan iritasi bagi jaringan gigi dan perlekatan yang baik. Salah satu bahan tumpatan yang sering dipakai oleh dokter gigi ialah glass ionomer cements atau Semen Ionomer Kaca (SIK).

Sejak tahun 1970an SIK sudah digunakan sebagai bahan tumpatan. SIK merupakan bahan tumpatan yang mampu melepaskan 
ion fluor lebih banyak dibandingkan material lain seperti resin komposit sehingga dapat mencegah perkembangan karies di dalam rongga mulut. Penelitian lain menyatakan bahwa material ini juga biokompatibel di dalam rongga mulut, normal ekspansinya hampir sama dengan struktur gigi dan perlekatannya baik. ${ }^{1}$ Karena keunggulan-keunggulan tersebut maka bahan tumpatan SIK banyak digunakan oleh dokter gigi.

Karies gigi adalah penyakit infeksi dan merupakan suatu proses demineralisasi yang progresif pada jaringan keras permukaan mahkota dan akar gigi yang dapat dicegah. ${ }^{2}$ Karies gigi merupakan penyakit yang paling banyak dijumpai di rongga mulut sehingga merupakan masalah utama kesehatan gigi dan mulut. Sampai saat ini penyakit ini sering tidak mendapat perhatian dari masyarakat.

Balai Pengobatan Rumah Sakit Gigi dan Mulut (BP-RSGM) Universitas Sam Ratulangi merupakan rumah sakit yang didirikan pada tahun 2010 berlokasi di pusat kota Manado. Pasien yang menerima perawatan bahan tumpatan SIK cukup banyak namun sampai saat ini masih kurang penelitian mengenai tumpatan SIK di balai pengobatan tersebut. Inilah yang membuat penulis tertarik untuk mengadakan suatu penelitian mengenai penggunaan tumpatan SIK.

\section{METODE PENELITIAN}

Jenis penelitian ini merupakan penelitian deskriptif. Penelitian dilakukan di bagian Rekam Medis BP-RSGM Universitas Sam Ratulangi pada bulan Juni 2013. Populasi dalam penelitian ini ialah rekam medis pasien yang tercatat menggunakan bahan restorasi SIK di BP-RSGM Universitas Sam Ratulangi pada bulan januari 2011 sampai desember 2012. Pengambilan sampel menggunakan metode Total Sampling. Data yang diambil meliputi:

1. Tahun penumpatan: pasien restorasi SIK yang tercatat di rekam medis pada bulan januari 2011 sampai desember 2012

2. Jenis kelamin ialah jenis kelamin subjek yaitu laki-laki dan perempuan.

3. Usia pasien, dibagi menjadi 4 kategori: ${ }^{3}$
a) Anak-anak ( $\leq 12$ tahun)
b) Remaja (13-18 tahun)
c) Dewasa (19-55 tahun)
d) Lansia ( $\geq 56$ tahun)

4. Regio gigi yang ditumpat SIK:
a) Anterior
b) Posterior

5. Periode gigi yang ditumpat SIK:
a) Sulung
b) Permanen 


\section{HASIL}

Penelitian berlangsung selama satu bulan.

Dari hasil penelitian didapatkan yaitu rekam medis dari pasien yang direstorasi SIK pada tahun 2011 dan tahun 2012 yang berjumlah 247 pasien dengan jumlah 355 gigi yang ditumpat. Mahasiswa koas yang masuk pada tahun 2010 berjumlah 48 orang, 2011 berjumlah 47 orang dan pada tahun 2012 berjumlah 60 orang.

\section{Distribusi Frekuensi Berdasarkan}

\section{Tahun Penumpatan}

Data yang diambil yaitu tahun 2011 dan tahun 2012. Data dua tahun terakhir ini diharapkan dapat mewakili data frekuensi penggunaan SIK pada tahun 2010 (Gambar 5).

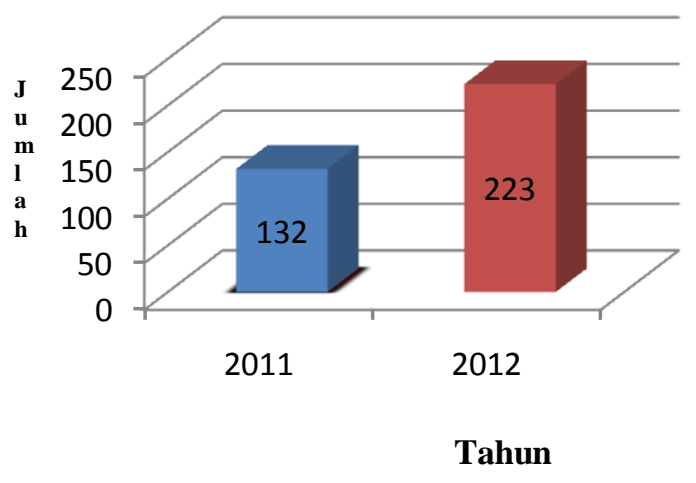

\section{Penumpatan}

Gambar 6. Distribusi frekuensi berdasarkan tahun penumpatan

Gambar 6 menunjukkan bahwa penggunaan SIK paling banyak di tahun 2012, yaitu sebanyak 223 tumpatan (62,8\%) dibandingkan pada tahun 2011 yaitu sebanyak 132 tumpatan $(37,2 \%)$

\section{Distribusi Frekuensi Berdasarkan} Usia Pasien

Berikut merupakan hasil penelitian mengenai distribusi penggunaan SIK berdasarkan kelompok usia pasien (Gambar 6).

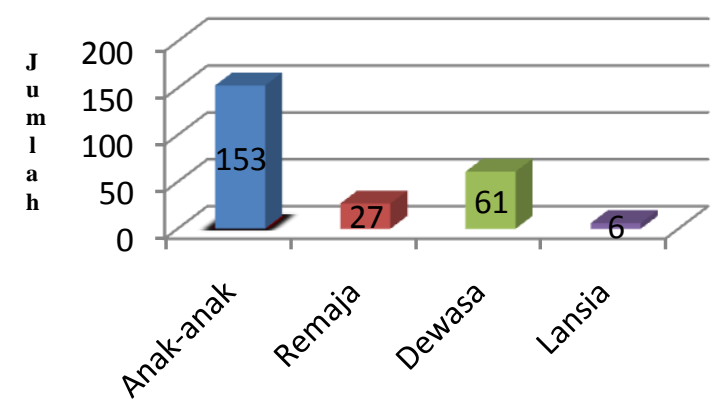

Usia

Gambar 7. Distribusi frekuensi berdasarkan usia pasien

Gambar 7 menunjukkan bahwa pasien anak-anak 153 orang $(61,9 \%)$ lebih sering di restorasi SIK dibandingkan remaja 27 orang $(10,9 \%)$, dewasa 61 orang $(24,7 \%)$ dan lansia 6 orang $(2,5 \%)$.

\section{Distribusi Frekuensi Berdasarkan}

\section{Jenis Kelamin}

Berikut merupakan hasil penelitian mengenai distribusi penggunaan SIK berdasarkan jenis kelamin pasien (Gambar 7). 


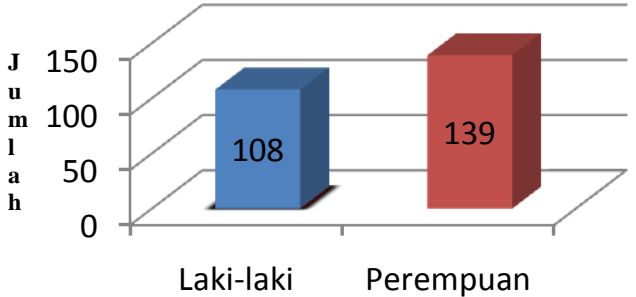

Jenis Kelamin

Gambar 8. Distribusi frekuensi berdasarkan jenis kelamin

Gambar 8 menunjukan bahwa perawatan restorasi SIK paling sering diterima oleh pasien perempuan yang berjumlah 139 orang $(56,3 \%)$, dibandingkan pasien lakilaki yang berjumlah 108 orang $(43,7 \%)$.

\section{Distribusi Frekuensi Berdasarkan}

\section{Regio Gigi yang Ditumpat}

Berikut merupakan hasil penelitian mengenai distribusi penggunaan SIK berdasarkan regio gigi yang ditumpat (Gambar 8)..

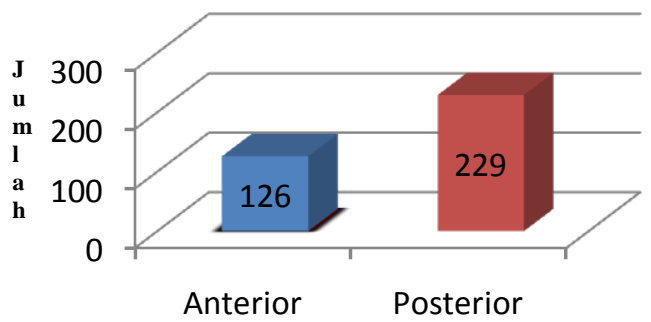

Regio Gigi

Gambar 9. Distribusi frekuensi berdasarkan regio gigi

Gambar 9 menunjukkan bahwa tumpatan dengan SIK banyak dilakukan pada regio gigi posterior yang berjumlah 229 tumpatan $(64,5 \%)$ dibandingkan pada regio gigi anterior yang berjumlah 126 tumpatan $(35,5 \%)$

\section{Distribusi Frekuensi Berdasarkan}

\section{Periode Gigi yang Ditumpat}

Berikut merupakan hasil penelitian mengenai distribusi penggunaan SIK berdasarkan elemen gigi yang ditumpat (Gambar 9).

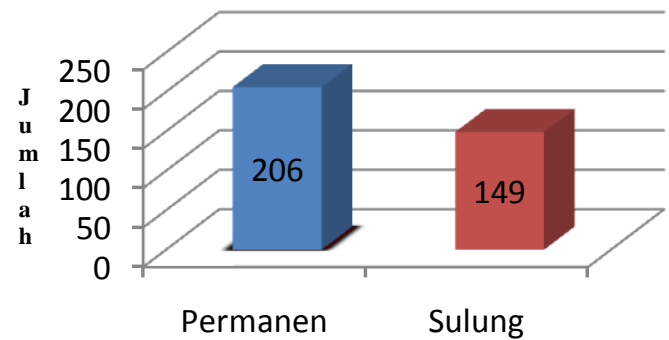

\section{Regio Gigi}

Gambar 10. Distribusi frekuensi berdasarkan elemen gigi

Gambar 10 menunjukkan bahwa tumpatan dengan SIK banyak dilakukan pada gigi permanen yang berjumlah 206 gigi (58\%) dibandingkan gigi sulung yang berjumlah 149 gigi (42\%)

\section{PEMBAHASAN}

1. Penggunaan SIK Berdasarkan Tahun Penumpatan

Berdasarkan tahun penumpatan, dari hasil penelitian yang diperoleh, penggunaan SIK sebagai bahan tumpatan meningkat di tahun 2012 yaitu berjumlah 223 tumpatan $62,8 \%$ bila dibandingkan dengan penggunaan SIK pada tahun 2011 yang berjumlah 132 tumpatan 37,2\%. Dari data ini menunjukkan bahwa penggunaan SIK di BP-RSGM Universitas Sam Ratulangi meningkat dari tahun ke tahun. Dalam hal 
ini berhubungan dengan banyaknya mahasiswa koas yang masuk dan meningkat dari tahun 2011-2012 di BPRSGM Universitas Sam Ratulangi.

Jumlah mahasiswa koas yang praktek bila di tambah dengan tahun 1010 dan tahun 2011 berjumlah 95 orang dan pada tahun 2012 total 155 orang. Mahasiswa koas yang bertambah, mempengaruhi peningkatan pemakaian SIK tiap tahunnya karena SIK juga merupakan salah satu requirement bagi mahasiswa koas.

\section{Penggunaan SIK Berdasarkan Usia Pasien}

Berdasarkan usia pasien, pasien anakanak $61,9 \%$ jauh lebih banyak mendapatkan perawatan restorasi SIK dibandingkan pasien remaja 10,9\%, dewasa $24,7 \%$ dan lansia 2,5\%. Hal ini bisa disebabkan karena pada usia anakanak lebih mudah terjadinya karies.

Vipeholm (1945-1953) menyimpulkan bahwa konsumsi makanan dan minuman yang mengandung gula di antara jam makan dan pada saat makan berhubungan dengan peningkatan karies yang besar. Faktor makanan yang dihubungkan dengan terjadinya karies adalah jumlah fermentasi, konsentrasi dan bentuk fisik (bentuk cair, tepung, padat) dari karbohidrat yang dikonsumsi, retensi di mulut, frekuensi makan dan snacks serta lamanya interval waktu makan. Anak yang berisiko karies tinggi sering mengkonsumsi makanan dan minuman manis di antara jam makan.

Banyak penelitian juga menunjukkan bahwa prevalensi karies lebih tinggi pada anak yang berasal dari status sosial ekonomi rendah. Hal ini dikarenakan anak dari status ini makan lebih banyak makanan yang bersifat kariogenik, rendahnya pengetahuan akan kesehatan gigi dapat dilihat dari kesehatan mulut yang buruk, karies tinggi pada keluarga (karies aktif pada ibu), jarang melakukan kunjungan ke dokter gigi sehingga banyak karies gigi yang tidak dirawat. ${ }^{2}$

\section{Penggunaan SIK Berdasarkan Jenis Kelamin}

Berdasarkan jenis kelamin, pasien perempuan 56,3\% lebih banyak mendapatkan perawatan restorasi dibandingkan pasien laki-laki 43,7\%. Hal ini disebabkan oleh kepedulian perempuan terhadap penampilannya.

Hasil penelitian tersebut tidak jauh berbeda dengan penelitian yang dilakukan di Rumah Sakit Gigi dan Mulut Pendidikan (RSGMP) Fakultas Kedokteran Gigi Universitas Indonesia (FKG UI) dimana pasien perempuan $(61,5 \%)$ merupakan pasien yang paling sering melakukan perawatan restorasi SIK dibandingkan laki-laki $(38,5 \%) .{ }^{4}$

Umumnya perempuan tidak merasa percaya diri jika keadaan rongga mulutnya tidak bersih, misalnya terdapat banyak karies gigi sehingga menimbulkan bau mulut hal ini lah yang mendorong banyak pasien perempuan cenderung untuk pergi ke dokter gigi dan melakukan perawatan. Sedangkan laki-laki sebagian besar tidak terlalu memperhatikan penampilannya termasuk kesehatan gigi dan mulutnya.

Hal tersebut juga sesuai dengan hasil survei yang dilakukan di Amerika oleh American Dental Association (ADA) yang menyatakan bahwa kaum perempuan $89 \%$ lebih rutin ke dokter gigi untuk merawat giginya dibandingkan lakilaki. $^{5}$ 
4. Penggunaan SIK Berdasarkan Regio

\section{Gigi}

Berdasarkan regio gigi yang ditumpat, diperoleh bahwa regio posterior lebih banyak $64,5 \%$ dilakukan penumpatan dibandingkan dengan regio anterior $35,5 \%$. Pada regio posterior, gigi yang sering mendapatkan perawatan SIK adalah gigi molar. Permukaan geligi poterior sulung dan permanen sering ditemukan adanya karies kerena morfologi pit dan fisura yang dinyatakan sebagai daerah yang ideal untuk terjadinya retensi sisa makanan dan bakteri penyebab karies. ${ }^{6,7}$ Pit dan Fisura pada permukaan oklusal menunjukkan gambaran khas dan relatif yang menyebabkan tingginya insidensi karies karena tak dapat dibersihkan secara mekanis oleh bulu sikat. ${ }^{8,9}$

\section{Penggunaan SIK Berdasarkan \\ Periode Gigi}

Berdasarkan periode gigi yang ditumpat, diperoleh bahwa gigi permanen lebih banyak $58 \%$ dilakukan penumpatan SIK dibandingkan dengan gigi sulung $42 \%$. Salah satu indikasi SIK ialah untuk melindungi email gigi permanen. Karakteristik yang dimiliki oleh SIK ialah daya adhesinya terhadap struktur hidroksiapatit email dan dentin untuk jangka waktu yang tidak terbatas. ${ }^{10}$

Penyebab utama karies adalah proses demineralisasi pada email. Email merupakan struktur keras dalam tubuh. Kandungan email terdiri dari $96 \%$ bahan inorganik dan $4 \%$ air, bahan organik serta karbonat $(4 \%)$, sodium $(0,6 \%)$, magnesium $(1,2 \%)$, klorida $(0,2 \%)$ dan sejumlah kecil fluorida $(0,01 \%)$.
Email pada gigi mempunyai ketebalan yang berbeda pada tiap bagian dan bervariasi diantara jenis gigi, maksimum 2,5mm. Pada gigi permanen emailnya lebih tebal dari gigi sulung. Hal ini disebabkan karena terjadinya proses remineralisasi sehingga kandungan mineral pada email gigi permanen lebih banyak dibandingkan gigi sulung. ${ }^{11}$

Mahkota gigi yang sudah tumbuh ke rongga mulut dan maturasinya belum sempurna akan sangat peka terhadap perubahan mineral dalam rongga mulut. Bila pada tahap maturasi email terdapat fluor didalam rongga mulut, maka ion fluor dengan cepat berikatan dengan kristal hidroksiapatit membentuk fluoroapatit yang lebih tahan terhadap pelarutan asam. Email bagian dalam, yang pertama larut, sedang bagian permukaan sukar larut karena kandungan fluoridanya lebih tinggi. Reaksi ini sebagian menjelaskan peran fluor dalam pencegahan karies saat proses karies diawali oleh demineralisasi email. Reaksi remineralisasi sangat diperkuat oleh adanya keberadaan fluor. ${ }^{12}$

\section{KESIMPULAN}

Berdasarkan penelitian di BP-RSGM Universitas Sam Ratulangi dapat disimpulkan bahwa;

1. Penggunaan bahan tumpatan SIK pada tahun 2012 dengan jumlah 223 tumpatan (62,8\%) mengalami peningkatan dibandingkan tahun 2011 yang berjumlah 132 tumpatan $(37,2 \%)$

2. Pemakaian bahan tumpatan SIK yang paling banyak pada pasien dengan 
kategori anak-anak yang berjumlah 153 pasien $(61,9 \%)$ dibandingkan dengan kategori usia lainnya.

3. Perawatan SIK lebih sering diterima oleh pasien perempuan dengan jumlah 139 pasien (56,3\%), dibandingkan dengan pasien laki-laki yang berjumlah 108 pasien $(43,7 \%)$

4. Regio gigi yang lebih banyak mendapatkan perawatan yaitu regio posterior dengan jumlah 229 tumpatan (64,5\%) dibandingkan dengan regio anterior yang berjumlah 126 tumpatan $(35,5 \%)$.

5. Periode gigi yang lebih banyak mendapatkan perawatan SIK yaitu gigi permanen dengan jumlah 206 gigi (58\%) dibandingkan dengan gigi sulung yang berjumlah 149 gigi $(42 \%)$.

\section{SARAN}

1. Penggunaan SIK pada karies gigi diharapkan dapat mencegah kerusakan lebih lanjut.

2. Pemeriksaan gigi sedini mungkin bahkan pada saat masih anak-anak.

3. Perawatan gigi tidak hanya pada perempuan, pada laki-laki juga harus lebih ditingkatkan.

\section{DAFTAR PUSTAKA}

1. Ningsih DS, Noerdin A, Herda E. Perbedaan kekerasan permukaan dua jenis hibrid ionomer setelah direndam di dalam larutan demineralisasi-remineralisasi. Cakradonya dental journal 2010;2:(1):83158

2. Angela, Ami. Pencegahan primer pada anak yang beresiko karies tinggi. Majalah kedokteran gigi (Dent.J) 2005;38:(3):130-134

3. Cohen S, Richard C. Burns. Pathways of the pulp. $9^{\text {th }}$ Ed. St. Louis: Mosby. 2004. p. 21-3

4. Indriani. Survei pemaparan penggunaan amalgam, GIC dan resin komposit sebagai bahan tumpat gigi di RSGMP FKG UI pada tahun 2005, 2006, dan 2007. Fakultas Kedokteran Gigi Universitas Indonesia; 2008.

5. Heniputra. Wanita lebih peduli masalah kesehatan. [online]. [citied 2013 22 Oktober]; available from URL: http://heniputra.com/wanita-lebih-pedulimasalah-kesehatan.html

6. Martheson RJ, Primosch R. Sealant and preventive resin restorations. Fundamentals of pediatric dentistry. Ed 3. St. Louise: quintenssence Publishing Co. Inc. 1995: 119-35

7. Craig RG, Powers JM. Restorative dental material. $11^{\text {th }}$ ed. St. Louis: Mosby Inc. 2002: 234-76 
8. Finn SA. Clinical pedodontics, $4^{\text {th }}$ ed. 1973; Toronto: W.B. Sounders Co

9. Mc.Donald RE and Avery DR. Oral development and histology. Second edition, 2003; New York: Thime Medical Publishers, Inc

10. Santoso $\mathrm{P}$, Partosoedarmo $\mathrm{M}$, Wintarsih O. Kebocoran Apikal Pada Irigasi Dengan EDTA Lebih Kecil Dibandingkan Yang Tanpa EDTA. Jurnal PDGI 2009; 58(2): 14-19

11. Fauziah E, Soenawan H, Suwelo IS. Kandungan Unsur Florida Pada Email
Gigi Tetap Muda Yang Ditumpat Semen Ionomer Kaca dan Kompomer. Indonesian Journal of Dentistry 2008; 15(3): 205-211

12. Soemartono SH, Suwelo IS, Yuliarti RT. Kandungan Unsur Fluor Pada Email Gigi Tetap Muda Dengan Tumpatan Semen Ionomer Kaca Viskositas Tinggi. Indonesian Journal of Dentistry 2008; 15(2): 163-168 